\title{
Psalm 101: A supplication for the restoration of society in the late post-exilic age
}

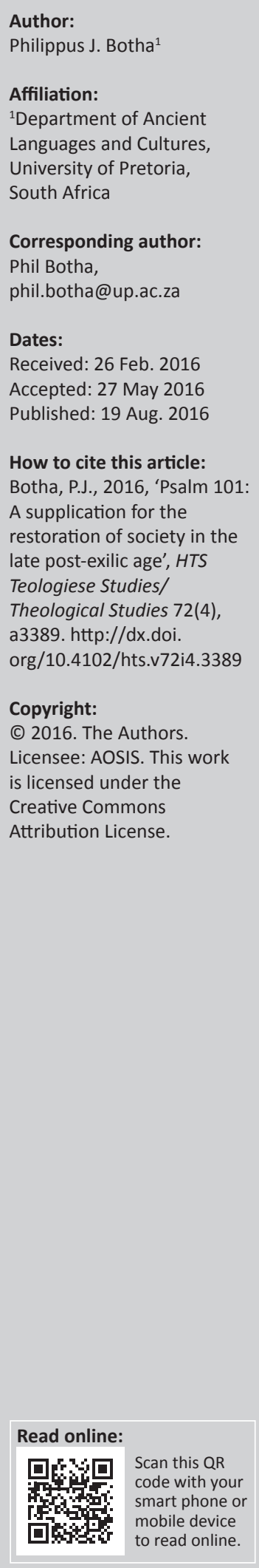

This article investigates the form and purpose of Psalm 101 from two perspectives: As a unique composition from the late Persian or early Hellenistic period, and in terms of its function within the context of Book IV of the Psalter. It is suggested that it was designed by exponents of wisdom and Torah piety to serve as a 'royal psalm' at exactly this location in the Psalter. It was meant to offer support to faithful Yahwists by criticising the apostate Judean aristocracy of its time of origin and serve as a prayer with which Yahweh could be beseeched to establish his righteous rule by judging evildoers and thus vindicating the faithful.

\section{Introduction}

This article has a dual purpose: On the one hand, it offers an investigation of the form and function of Psalm 101 as a text on its own, but it also proposes to describe the probable role that was assigned, by its editors, to this composition in Book IV of the Psalter. It will therefore initially be investigated from an intratextual perspective and afterwards defined in terms of intertextual relations: correspondence with other, similar psalms and possible seminal sources that played a role in its composition, but also its integration into Book IV of the Psalter.

Psalm 101 is a problematic text in many respects. Its Gattung and, consequently, its purpose, its unity, segmentation, and time of origin have all been interpreted in widely divergent ways. In terms of Gattung, it was classified by Hermann Gunkel as a 'royal psalm' and this classification is still accepted by the majority of investigators, although Gunkel's views are almost always modified to some extent. ${ }^{1}$

The unity of Psalm 101 is also contested. ${ }^{2}$ It has features of a hymn in its first poetic line (v. 1bc), but this style is abandoned, in the view of many investigators, from verse 2 onwards. Gunkel seeks to overcome this 'problem' by 'correcting' the text in verse $2{ }^{3}$ while Mowinckel thinks that it is as it should be, since the liturgical setting he envisages necessitated a creative combination of 'elements from hymn and psalm of lament and prayer' to form a new unity (Mowinckel 1962:66). Seybold (1996:393) regards only verses 2aa, 3-5, and 7 as remnants of an original composition ('Grundshicht und Vorlage') and consequently finds extrapolations in verses 1, 2, 6, and 8, while the editor from a later age in his view also made small changes to verses $2,3,4$, and 5 . As Hossfeld and Zenger (2011:12) remark, such a complex literary-critical solution breaks down in view of the finely balanced structure of the psalm.

Even the strophic structure that the psalm was supposed to reflect in its final form is contested. According to Pieter van der Lugt (2014:109), 'Psalm 101 poses no problems' as far as the delimitation of its verse lines and cola is concerned, but there is a lack of consensus regarding the macrostructure of the poem. Many regard the psalm to be separated between verses 5 and 6 to form two main parts. Van der Lugt himself proposes that it consists of two main units or 'cantos', consisting of verses 1-5 and 6-8, which form a linear parallelism in terms of their subject matter (Van der Lugt 2014:110).

1.Gunkel (1986:433-434) thinks that it was a kind of proclamation or speech used by a king on the day of ascension to the throne in which he would list his intentions and make promises about the quality of his reign. Cf. also Gunkel $(1985: 140,145)$. Mowinckel (1962:47, 56, 65-67) agrees, but thinks that the promise to rule wisely would have been repeated yearly at a kind of New Year's Festival. Kraus
$(1966: 689)$ and Weiser (1975:648-649) basically accept Gunkel's view, but Seybold (1996:393) regards only certain sections of the psalm $(2 \mathrm{a \alpha}, 3-5,7)$ as a remnant of such a pre-exilic political and ethical 'Fürstenspiegel'.

2.Loretz (1988:165) is convinced that Psalm 101:1-2a displays 'bereits im ersten Bikolon unverkennbare Kennzeichen redaktioneller Tätigkeit'. The same applies, in his view, to Psalm 101:8 (p. 167). In Seybold's view, the original psalm was adapted for use by a priestly Tätigkeit'. The same applies, in his view, to Psalm 101:8 (p. 167). In Seybold's view, the original psalm was adapted for use by a priestly
official as a prayer to express his own religio-political ideal. To achieve this, he made small changes and introduced the theme of confrontation between the righteous (vv. 2,6) and the wicked (v. 8). Cf. Seybold (1996:393).

3.Gunkel (1986:432, 434); cf. also Loretz (1988:141) 
The solutions to many of the research questions listed above are most probably interrelated: Psalm 101 seems to have been designed and composed in the late post-exilic age to serve at this particular junction in the Psalter as a 'royal psalm'. It displays features commonly found in other psalms composed or edited by exponents of wisdom and Torah piety, inter alia, its homogenous parallelistic form. In view of the probability that Psalm 101 also displays influence from Proverbs 1-9 (which was most probably put together in its present form only at about 300 B.C.E., cf. Loader [2014:9]), it will be argued that it is improbable that the psalm ever served as a formulary at the enthronisation of a Judean king. It was probably devised to offer support to faithful Yahwists in the late Persian or early Hellenistic period by criticising the deviant Judean aristocracy who collaborated with Persian or Greek overlords to the detriment of their own people. At the same time, it constituted a supplication by the righteous speaker, and by all who meditated on the psalm, to Yahweh to establish his rule on earth by vindicating the faithful and by judging the evildoers. This the poet achieved through emphasis on the intimate relationship between Yahweh and his royal representative.

\section{Form and purpose of Psalm 101 The text as a poetic composition}

\begin{tabular}{|c|c|c|c|}
\hline \multirow{2}{*}{ I A } & & la לְדָוד מִזְֶֶׁוֹר \\
\hline & 1 & 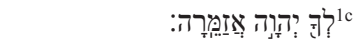 & 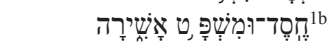 \\
\hline & 2 & 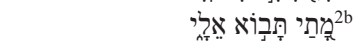 & 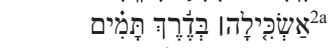 \\
\hline & 3 & 2d & 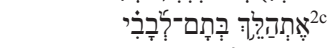 \\
\hline B & 4 & 3b & 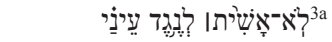 \\
\hline & 5 & 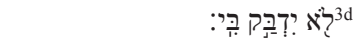 & (3c \\
\hline & 6 & 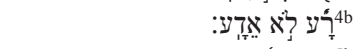 & 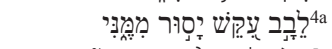 \\
\hline II C & 7 & 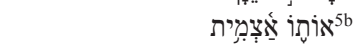 & 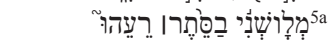 \\
\hline & 8 & 每 & 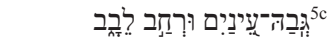 \\
\hline D & 9 & 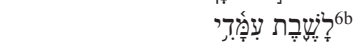 & 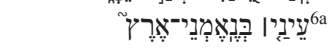 \\
\hline & 10 & 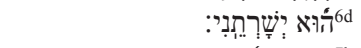 & 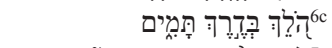 \\
\hline E & 11 & 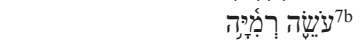 & 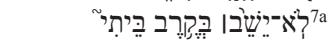 \\
\hline & 12 & 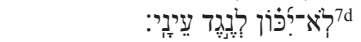 & 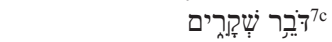 \\
\hline $\mathrm{F}$ & 13 & 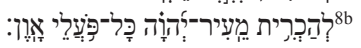 & 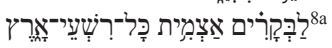 \\
\hline
\end{tabular}

\section{Translation}

${ }^{1 a}$ Of David. A psalm.

I A $1^{1 \mathrm{~b}}$ Of faithful love and justice ${ }^{1}{ }^{1}$ to you, Yahweh, I will I will sing;

$2{ }^{2 a}$ I will give heed to a blameless way:

$3{ }^{2 c}$ I will walk in integrity of heart

B $4{ }^{3 a}$ I will not set before my eyes

5 3cThe doing of devious things I hate;

sing a psalm.

${ }^{2 b}$ When will you come to me?

${ }^{2 \mathrm{~d}}$ within my house.

${ }^{3 b}$ anything that is worthless.

3dit shall not cling to me.

$6{ }^{4 a} \mathrm{~A}$ false heart shall depart ${ }^{4 \mathrm{~b}}$ evil I will not know. from me;

II C $7^{5 a}$ The one who secretly $\quad{ }^{5 b}$ him I will destroy; slanders his friend,

$8{ }^{5 c}$ the one with haughty eyes ${ }^{5 \mathrm{~d}}$ him I will not and an arrogant heart, tolerate.
D $9{ }^{6 a}$ My eyes will be on the faithful of the land

$10^{6 \mathrm{C}} \mathrm{He}$ who walks in a blameless way,

E $11^{7 \mathrm{a}} \mathrm{He}$ shall not dwell in my ${ }^{7 \mathrm{~b}}$ who practices deceit; house

$12^{7 \mathrm{c} H e}$ who speaks lies,

$$
\begin{aligned}
& { }^{7 \mathrm{~d}} \text { shall not be } \\
& \text { established before my } \\
& \text { eyes. }
\end{aligned}
$$

F $13^{8 a}$ In the mornings I will ${ }^{8 b}$ to cut off from the city destroy all the wicked of of Yahweh all the land,

\section{Notes on the text of Psalm 101}

v. 2a דרך תמים is probably not 'the way of the blameless', but 'the blameless way'. The root of the adjective is תמים רמם 'תמים thus functions as a masculine singular absolute form. is thus considered here to be a masculine noun. ${ }^{5}$

v. $2 b$ 'When will you come to me': This phrase has proven notoriously difficult to explain. It reflects the style of a lament, which thus clashes with the hymnic opening line in the view of many investigators. Seybold (1996:393) describes it as a crux and asks whether it should not possibly be regarded as a gloss. Many exegetes have given in to the temptation to emend the text so as to obtain an explicable or smoother reading, but there is no textual justification to do this. ${ }^{6}$ It is regarded, in this article, as an expression of the intimate relationship between Yahweh and his representative and the desire that Yahweh's rule will be established on earth.

v. 5a 'The one who secretly slanders...': According to BHS, the Cairo Geniza and a number of manuscripts have

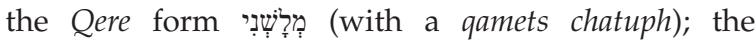
Masoretes vocalised it as (with cholem as vowel). There is no difference in meaning between the two

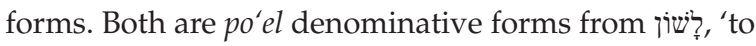
slander, injure with the tongue' (cf. Gesenius 1910:§

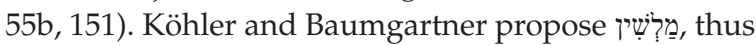
the hif' il participle with the same meaning, 'to slander' (cf. Dietrich et al. 2013:274).

It is proposed here that Psalm 101 consists of 13 verse lines (numbered 1-13 to the left of the Hebrew text and of the translation above), six strophes (A-F), and two stanzas (I-II). The point of departure is the demarcation of verse lines on the basis of the Masoretic disjunctive accents. ${ }^{7}$ Internal

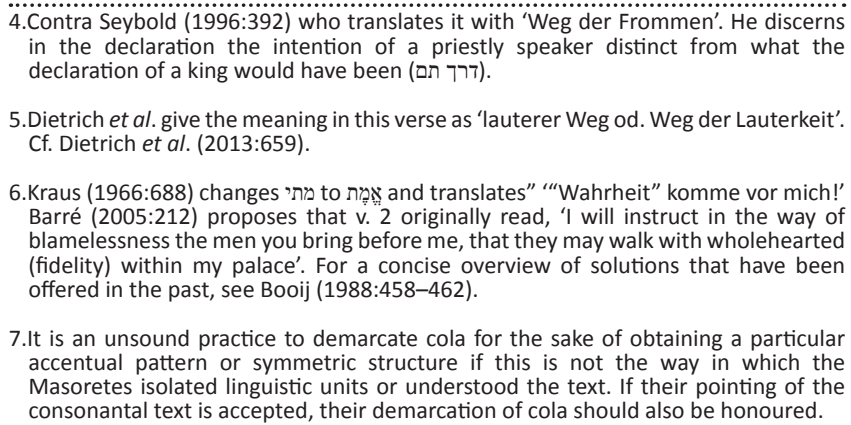


parallels and chiasms between the different cola of verse lines and also externally between cola of adjacent verse lines are identified first of all. Morphological order, the identity of the subjects of verbs, the repetition of stems or words, and the presence of semantic fields are then used to group verse lines together in order to demarcate strophes. Stanzas are identified on the same basis, although the inclusion and antithesis or parallelism of strophes, as a whole, can also play an important role.

Verse line 1 (v. 1bc) is the only verse line that mentions singing. However, Yahweh is addressed directly and this is also the case in verse $2 b$ of verse line 2 . Therefore, verses 1 and 2 (verse lines 1-3) are grouped together as one strophe, strophe A. ${ }^{8}$ The 'faithful love' (משכד) and 'justice' (משפט) of Yahweh mentioned in verse $1 \mathrm{~b}$ point to the foundations of a social-ethically organised society (cf. also Seybold 1996:393-394), and thus serve as introduction to the discussion found in the psalm as a whole about commendable and unacceptable human conduct. ${ }^{9}$ Yahweh's 'faithful love' and 'justice' should become visible through the propagation of these characteristics of him under the rule of the speaker.

The use of the two voluntative forms in verse $1 \mathrm{~b}$ and $\mathrm{c}$ and in verse $2 \mathrm{a}$ also point to a close connection between verse lines 1 and 2. Verse line 3 must also be connected to verse lines 1 and 2 since the Masoretes considered it to be part of the same verse that begins at verse $2 a$. An external parallel also exists between verses $2 a$ and $2 c$ (verse lines 2 and 3) with the repetition of the metaphor of life as a journey (cf. 'way', 'walk') and of the related words תמים ('blameless', 'integrity') that are found in verses 2a and 2c.

Strophe B (vv. 3-4) is demarcated as a unit because of the repetition of ל 'not' in verses 3a, 3d, and 4b. Verse lines 4, 5, and 6 are all parallel: the words for 'hate' and 'shall depart' similarly convey the feeling that there will be no association between the psalmist and immoral acts or intentions. The four stichs of verse lines 4 and 5 are arranged chiastically, while verse lines 5 and 6 form a parallel. Verse lines 4, 5, and 6 (strophe B) also form a series of actions: See no evil, do no evil, and think no evil.

Strophes A and B together constitute stanza I which has, as its theme, integrity in the personal sphere of the speaker-dedication to Yahweh and a consequent striving to be blameless.

Stanza II (vv. 5-8) moves to the public domain, namely, the dedication of the royal speaker or 'king' to Yahweh as manifested in his relationship with other people. ${ }^{10}$ The

8. Hossfeld and Zenger (2011:13) are therefore not correct in interpreting v. 1 as being 'slightly set off' from the rest of the psalm and thus assuming the role of a superscription.

9.Kraus (1966:692) describes v. 1 as providing 'ein Gesamtbild' of Psalm 101. He (p. 690) also points to the close connection between these two concepts in Hosea 12:7, Micah 6:8 and Matthew 23:23. In the post-exilic wisdom composition of Psalm 33:5, the two words are also used, together with 'righteousness' (צדקה) as characteristics of Yahweh. The same applies to Psalm 89:15, 119:15, Jeremiah as characteristics of Yahweh. The same applies to Psalm 89:15, 119:15, Jeremiah $9: 23$, and Hosea 2:21. In some of these texts, they form part of a bigger semantic words are used to describe human obligations to one another (cf. Isa 16:5; Hos words are used to describe huma
12:7; Micah 6:8, and Zech 7:9).

10. Hossfeld and Zenger (2011:13) also identify a two-part structure, but strangely include v. 5 as part of the private behaviour and avoiding $\sin (v v .2-5)$, while $6-8$ is described by them as being 'about forensic activities and avoiding the wrong society'. 'king' undertakes to associate with certain people and to disassociate himself from others, while he also promises to prosecute certain categories of transgressors. Strophes C (v. 5 or verse lines 7-8), D (v. 6, verse lines 9-10), and E (v. 7, verse lines 11-12) each consists of two verse lines, while strophe F (v. 8 and verse line 13) forms the conclusion with one longer verse line $(3+4) .{ }^{11}$ The topic of strophe $C$ is the aversion of the 'king' to people who sin in a less perceivable way: secretly slandering a neighbour or displaying arrogance against others or against God. One wonders how the 'king' would be able to identify those offenders who might be known to Yahweh only. In fact, the boundaries between Yahweh and the 'king' are vague in a number of verses in Psalm 101, something which has prompted John Kselman to propose that it is Yahweh who speaks in the second part and not the ' $\mathrm{king}^{\prime}{ }^{12}$ In my view, this overlap in their profiles is by design and serves to emphasise the close association between them. ${ }^{13}$ This is also the basis for the request in verse $2 b$ for Yahweh to visit the speaker.

In strophe D, the 'king' undertakes to care for those people who have an opposite frame of mind as the arrogant ones those who are faithful or truthful, and conduct their lives in an upright way, such as the 'king' himself also does (cf. v. 2a, c). Between strophes C and D, but also between strophes D and E, antitheses are created. The 'faithful of the land' (v. 6a and verse line 9) stand in contrast to the one who 'speaks lies' (v. 7c and verse line 12), and the faithful who will be allowed to 'dwell' with the 'king' (v. 6b and verse line 9), stand in contrast to the deceitful who will not be allowed to 'dwell' in his house (v. 7ab and verse line 11). The image of the 'king' keeping his eyes on the faithful (v. 6a and verse line 9) also stands in contrast to the image of the liars who will not be established before his 'eyes' (v. 7cd, thus verse line 12). Strophe F, in conclusion, forms an inclusio with strophe C (cf. the repetition of אצמית in verse $8 \mathrm{a}$ or verse line 13 after it was encountered in v. $5 \mathrm{~b}$ or verse line 7), but also with strophe A (cf. the repetition of the name יהוה that only occurs in vv. 1c or verse line 1 and verse $8 \mathrm{~b}$ or verse line 13). It also summarises the contents of stanza II by describing all the offenders listed in it as 'the wicked' and 'the evildoers'.

\footnotetext{
(footnote 10 continues...) They later (p. 14) identify three main segments: I Introduction to the Prayer
(1-2); II Private Activities of the Petitioner (3-5); III Forensic Activities of the Petitioner (6-8). In terms of the parallelistic structure of the psalm, it would be Petitioner (6-8). In terms of the parallelistic structure of the psalm, it would be
nice if the second stanza did begin with verse line $9(v .6)$, but there seems to

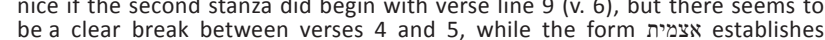
be a clear break between verses 4 and 5, while the form 1 establishes
inclusio between v. 5b and 8a. Kselman $(1985: 45-62,45)$ goes even further in inclusio between v. $5 \mathrm{~b}$ and $8 \mathrm{a}$. Kselman $(1985: 45-62,45)$ goes even further in
distinguishing between vv. $1-5$ and $6-8$. According to him, vv. 6-7 ('and perhaps v. $8^{\prime}$ ) no longer reflect the voice of the king, but constitute a divine oracle of Yahweh to the king.

11.Some investigators separate each stich into two segments, so that strophe F would also contain two verse lines. This is not the way in which the Masoretes interpreted the verse, however.

12.Cf. Kselman (1985:45, 51-57). Examples of expressions associated with Yahweh as subject, are: The eyes of Yahweh being kept on someone (v. 6; cf. Psalm 33:18; 34:16; Jeremiah 5:2 and 16:17); Yahweh 'cutting off' the memory of the evildoers (v. 8; cf. Psalm 34:17).

13. Kraus (1966:691) regards the king to be the representative of Yahweh in instances such as those in which he judges the thoughts of his subjects (v. 5); bans evil from his presence in verse 5 (לא אוכל, cf. Isaiah 1:13); and acts as a judge representing Yahweh in verse 8.
} 
Between strophes A, B, and C on the one hand and D, E, and $\mathrm{F}$ on the other, parallels are formed:

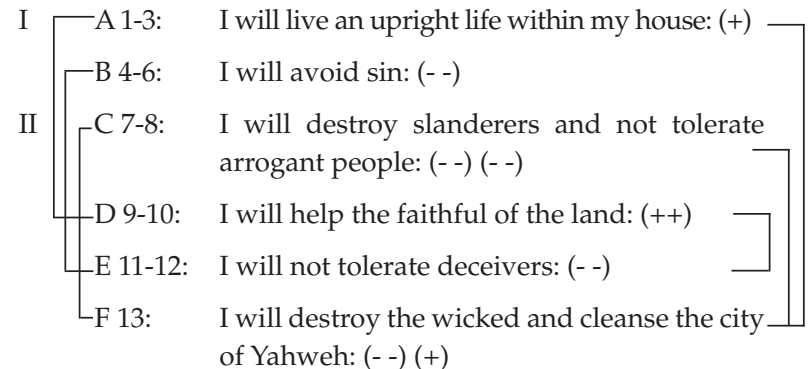

The idea of a blameless life forms a link between strophes A and D, on the one hand the personal 'walking' (הלך) in 'integrity of heart' (בתם־לבבי); on the other hand, the 'walking' (הלך) of the faithful 'in a blameless way' (בדרך תמים). The strong aversion to sin expressed in strophe $B$, is repeated in strophe E with regard to people who practice deceit and speak lies (cf. the repetition of לנגד עיני, 'before my eyes' in verse lines 4 and 12). The intention to destroy (צמת hif'il) slanderers expressed in strophe $\mathrm{C}$ is repeated with regard to the wicked of the land in strophe F. One should not be blind to the fact that although there is an antithesis between strophes $\mathrm{D}$ and E, together they contain echoes from strophe A ('walk blamelessly' and 'in my house'). The effect of the whole is that there are many connections running between the different parts of the psalm, but the inclusio (envelope structure) encompassing the poem as a whole, provided by the repetition of the name Yahweh in verse line 1 and verse line 13, and the inclusio encompassing stanza II, provided by the repetition of אצמית in verse lines 7 and 13, confirm the segmentation of Psalm 101 into two main parts.

From the structural analysis, it transpires that Psalm 101 is about choices of association and disassociation in one's personal life and in the public sphere, made by a hypothetical royal speaker or other high official. These choices are made on the basis of the speaker's dedication to Yahweh. The name Yahweh forms an inclusio around the psalm, and thus encompasses everything said about the 'king's' personal life (stanza I) and his relationship to his subjects (stanza II). The word-pair 'faithful love and justice' about which the psalmist wants to sing, is parallel to the words 'to you, Yahweh' in verse line 1. The speaker's desire, therefore, is to praise Yahweh for his characteristics of being loyal and exercising justice, and to honour him through his personal conduct and the exercise of his rule in his 'house', in the 'city of Yahweh', and in the 'land'.

The second and third verse lines make two promises about personal conduct ('I will pay wise attention to a blameless way', and 'I will walk in integrity of heart within my house'). Between these two pronouncements, which form an external parallel (דרך being parallel to המים הלך and being parallel to בתם־לבבי , there is the question, 'When will you come to me?' It would seem that this (rhetorical) question (verse line 2) stands in a parallel relationship with 'within my house' (verse line 3), at least in the thinking of the Masoretes, who grouped the four cola of verse 2 together as a linguistic unit. There is, in any case, a clear external parallel between verse lines 2 (v. 2ab) and 3 (v. 2cd). In preparation for a visit by Yahweh, the speaker thus undertakes to 'consecrate' his personal living space so that Yahweh will feel at home, so to speak. The speaker then proceeds to express disassociation from all things wicked and evil in verse lines 4, 5, and 6 (consisting of verses 3 and 4). He says that he will see no evil (not 'set' it before his 'eyes'), do no evil (he 'hates' the 'doing' of devious things), and know no evil (v. $4 \mathrm{~b}$ ). These three parallel verse lines therefore constitute a statement of total aversion to everything evil, similar to the intention to destroy 'all' the wicked and to cut off 'all' the evildoers expressed in verse line 13 (v. 8ab).

A similar process of consecration takes place in the second stanza of the psalm, but it now involves the public sphere. There, the speaker pronounces the desire to sanctify his 'house' (verse line 11) even further by excluding people with undesirable conduct from 'dwelling' with him and not 'establishing' them before his eyes (לאייכון ,לא ישב; verse lines 11 and 12). Eventually, the proposed programme of consecration also extends to the 'city of Yahweh' (verse line 13), and from that domain (hyperbolically) to the 'land' as a whole (verse line 13; cf. also verse line 7). As the speaker will not entertain any wickedness (דבר־בליעל, verse line 4) in his personal life 'before' his 'eyes' (לנגד עיני) (לבריני) and by extension in his 'house' (בקרב ביתי, verse line 3), so he will not tolerate deceivers and liars as employees in his 'house' (בקרבי) בקרב ביתי) and 'before' his 'eyes' (לנגד עיני, verse lines 11-12). As he 'hates' the 'doing' of devious things (v. verse line 5), so he also shies away from accommodating people who 'practice' deceit (verse line 11). Slanderers will be destroyed together with the 'wicked' (cf. verse line 7) and with 'all evildoers' (כל־פעלי און). As the speaker will know no evil (רע) in his personal life (verse line 6), so he will not tolerate evil (און) in the public sphere (verse line 13). All of this adds up to form numerous parallels between stanza I and stanza II, between the personal sphere and the public sphere. The concentric spheres of the 'king's' personal space, his palace, the city of Yahweh, and the land as a whole clearly signify the psalmist's concern with purity (cf. Botha 2004:725-741). This in turn confirms the surmise that Psalm 101 was composed from a religious or cultic point of view rather than from a political point of view.

The contents of Psalm 101 do not seem to have much to do with the actual enthronement of a new king. Although the impression is created that the speaker is a king or high official with a big palace where many people can reside and where many servants are needed, the pronouncements of association and dissociation have a performative effect of encouraging the reader to imitate the dedication of the speaker and pursue his objective of avoiding certain people and advancing the interests of certain other people. The psalm contains numerous verbs and expressions closely connected to ethical ideals; at the same time there are numerous verbs describing abhorrence of unethical or immoral conduct (Figures 1 and 2):

From this table, it is clear that the semantic field of things from which the speaker would like to dissociate himself is 


\begin{tabular}{|c|c|c|c|}
\hline Words of association & & Actions, attitudes, and persons & \\
\hline \multicolumn{4}{|l|}{ Stanza I } \\
\hline I will sing of + & (אשירה)(v. 1b) & faithful love and justice + & (חסד ומשפט) (v. 1b) \\
\hline I will sing to + & (אזמרה ל) (v. 1c) & you, Yahweh + & (לך יהוה) (v. 1c) \\
\hline I will give heed to + & (אשכילה ב) (v. 2a) & a blameless way + & (דרך תמים) (v. 2a) \\
\hline I will walk in + & (אתהלך ב) (v. 2c) & integrity of heart + & (תם־לבב) (v. 2c) \\
\hline \multicolumn{4}{|l|}{ Stanza II } \\
\hline My eyes will be on; to let them dwell with me + & (לשבת עמד) (עיני ב) (v. 6b) (לינ) (va) & the faithful of the land + & (נאמני־ארץ) (v. 6a) ( ) (ניץ) \\
\hline He will serve me + & (ישרתני) (v. 6d) & who walks in a blameless way + & (הלך בדרך תמים) (v. 6c) \\
\hline
\end{tabular}

FIGURE 1: The semantic field of association in Psalm 101.

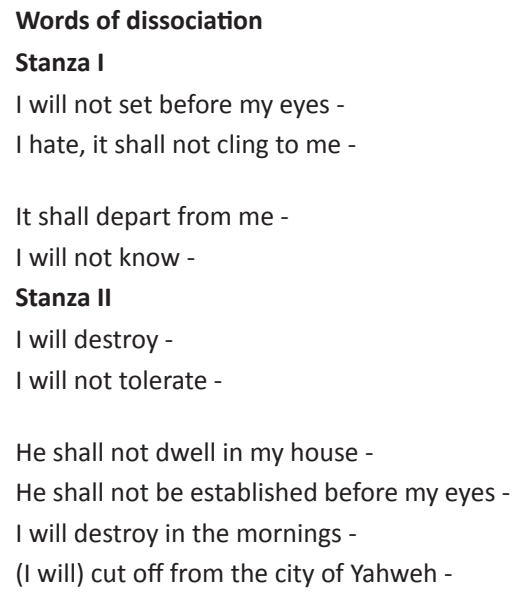

\section{Actions, attitudes, and persons}

anything that is base -

(דבר־בליעל) (v. 3b)

the doing of devious things -

(עשה־סטים) (va (vi 3c)

a perverted heart -

(לבב עקש) (v. 4a)

wickedness -

(า) (v. 4b)

the one who secretly slanders his friend - (מלושני בסתר) (v. 5a)

the one with haughty eyes and an

(גבה־עינים ורחב לבבר) (ve (vc) arrogant heart -

he who practices deceit -

he who speaks lies -

all the wicked of the land -

all evildoers -
(עשה רמיה) (v. 7b)

(דבר שקרים) (v. 7c)

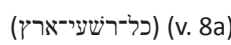

(כל־פעלי און) (v. 8b)

FIGURE 2: The semantic field of dissociation in Psalm 101.

larger than the semantic field of association. From this, one can in turn deduce that certain attitudes and social illnesses were considered by the psalmist or the editors of this text to be rampant in the Judean society of their time. The in-group of the author or editor were those who considered themselves to be 'the faithful of the land' who honestly tried to 'walk in integrity of heart' and 'in a blameless way'. Over against them, there were those whom they thought were 'secretly slandering' fellow Israelites, people with 'haughty eyes and an arrogant heart', people who practiced deceit, uttered lies, entertained 'worthless' and 'devious' things, had 'false' hearts and busied themselves with 'evil'. As a group, they could be described as 'the wicked of the land' and the 'evildoers'. One would have to think of fellow Jews, people who abandoned their religious roots, who possibly worshipped idols and became involved in collaborating with foreign powers to the advancement of their own interests and, conversely, to the detriment of their own people.

\section{The intertextual foundation of Psalm 101}

Psalm 101 clearly displays influence from post-exilic wisdom thinking. ${ }^{14}$ One of the clearest examples of this is found in the reference to a 'false heart' (לבב עקש) in verse 4a. A 'false heart' is denounced twice in Proverbs, namely, in Proverbs 11:20, in which the עקשי־לב, the people with a 'perverted heart', are 14. gratefully acknowledge the insights of Gosse (2008:85) in the following discussion. described as 'an abomination to Yahweh', while the תמימי דרך, the 'blameless of way', are described as his 'delight' in contrast; and Proverbs 17:20, which says that the עקש-לב, the person with a 'perverted heart', will not find 'good'. These three verses, Psalm 101:4, Proverbs 11:20, and Proverbs 17:20 are the only verses in the Hebrew Bible in which the concept of a 'false', or 'twisted', or 'devious' heart is found. On top of that, the expression, 'those of blameless way', (תמימי דרך) which forms the antithetic parallel to a perverted heart in Proverbs 11:20, is related to the דרך תמים in Psalm 101, namely, in verses 2 and 6. The adjective yִיקים occurs only 11 times in the Hebrew Bible, and all these instances are in wisdom texts or texts that were inspired by Proverbs. ${ }^{15}$ There is, consequently, reason to believe that not only verse 4 , but the whole composition was made after Proverbs 11:20 had come into circulation. ${ }^{16}$

The notion that Psalm 101 was composed at a time when Proverbs was already known in more or less its present form is strengthened by other correspondences between the psalm and Proverbs. Bernard Gosse (2008:85) points out that Psalm 101:5

15.Deut 32:5 (a wisdom composition which dates, according to Mathys (1994:166), at the earliest from the exilic period, 2 Sam 22:27 (= Psalm 18:27, in the editorial addition to Psalm 18); Psalm 101:4 (which must be left out of reckoning here in order to avoid circular reasoning); Proverbs $2: 15 ; 8: 8 ; 11: 20 ; 17: 20 ; 19: 1.22 .5$; and order to avoid circular reasoning); Proverbs 2:15; 8:8; 11:20; 17:20; $19: 1 ; 22: 5$; and 28:6. Gosse (2008:85) also considers Psalm 101:4 to have been directly influenced by Proverbs. The majority of the few instances in which the root in wisdom texts.
verb also as a

16.In Proverbs 10:29, the people who follow a 'blameless way' (תם דרך) are contrasted to the 'evildoers' (פעלי און). In Psalm 101:2c and 8b, these respective descriptions of
two groups of people are implicitly also contrasted, and the theological motif of Proverbs 10:29 affirmed. 
and Proverbs 30:10 are the only two instances in the Hebrew Bible in which the stem לשן is used as a verb and in both cases with the meaning 'to slander'. The hif'il is used in Proverbs 30:10, and the po' el in Psalm 101:5, but the meaning is the same.

Psalm 101:5 further also displays similarity to Proverbs 16:5, but especially to Proverbs 21:4. Arrogance is sometimes גבה or רום $)^{17}$ or the heart being 'high' (רום גבריה) or 'wide' (רחב), but when both are mentioned together, there seems to be a connection to Proverbs 21:4 ${ }^{19}$ :

The one who secretly slanders his friend, him I will destroy; the one with haughty eyes and an arrogant heart (גבהי־עינים ורחב לבב), I will not tolerate (Psalm 101:5)

Everyone who is arrogant in heart (כל־גביה-לב) is an abomination to Yahweh; he will certainly not go unpunished (Proverbs 16:5).

Haughty eyes and an arrogant heart (רום־עינים ורחב־לב), the lamp of the wicked, are a sin (Proverbs 21:4). ${ }^{20}$

Gosse (2008:85) further points out that the intention of the 'king' in Psalm 101:8, to destroy all the wicked of the land (כל־רשעי־ארץ) in the mornings and cut off from the city of Yahweh all who do evil (כל־פעלי און), is in perfect accord with the pronouncement in Proverbs 20:26 that a wise king 'winnows' the wicked (רשעים) and drives the (threshing) wheel over them. This remark about the extermination of the wicked in Psalm 101:8 also establishes, according to Gosse, a connection with Psalm 92:8, which says, 'though the wicked (רשעים) sprout like grass and all evildoers (כל־פעלי און) flourish, it happens so that they may be annihilated'; and with Psalm 94:16, 'Who will rise up for me against the transgressors (מרעים); who will stand up for me against the evildoers (פעלי און)?' To this rhetorical question, Psalm 101:8b offers a literal answer. John Kselman (1985:49) has argued that Proverbs 6:16-19 displays correspondence to various expressions used in Psalm 101, inter alia the fact that Yahweh 'hates' (שנא, cf. 101:3) seven things that he considers to be an abomination. Among those things and actions are haughty eyes' (עינים רמות, cf. 101:5), a 'lying' tongue (לשן שקר, cf. 101:7), a 'heart' devising evil schemes (לב חרש מחשבות און, cf. 101:4), a 'liar' (עד שקר, cf. 101:7), and a person who sows discord among 'brothers' (משלח מדנים בין אחים, cf. 101:5a). Only some words from these expressions occur in both contexts, but the similarity is clear enough.

Psalm 101 further also reflects a close relationship with Psalm 52, a post-exilic wisdom composition. ${ }^{21}$ The expression 'worker of deceit', using the word רמיה for deceit (עשה רמיה), occurs in only two verses in the Hebrew Bible, namely, Psalm 52:4 and Psalm 101:7. What is more, the parallel phrase in the next verse line in Psalm 101 (v. 7c), refers to 'he who speaks

17.E.g., 2 Kings 19:22; Psalm 18:28; 101:5; 131:1; Proverbs $6: 17$; $21: 3$; $30: 13$; Isaiah $2: 11 ; 5: 15 ; 10: 2 ; 37: 23$.

18.Deuteronomy 8:14; 17:20; 2 Chronicles 26:16; 32:2, 26; Psalm 101:5; 131:1; Proverbs 16:5; 18:12; 21:4; Jeremiah 48:29; Ezekiel 28:2, 5, 17; 31:10; Hosea 13:6; Daniel 11:12.

19.Psalm 101:5; 131:1; Proverbs 21:4; Isaiah 10:12.

20.Kraus (1966:691) also draws attention to this parallel.

21.Cf. Beyerlin (1980:95), who dates Psalm 52 to about 400 B.C.E. on the basis of its connections with Psalms 37, 49, and 73. lies' (דבר שקרים). The apostate, rich Judean who exploits his fellow citizens and who is addressed (by way of apostrophe) in Psalm 52:4, is also accused in Psalm 52:5 of loving evil (רע) more than good, and lying (שקר) more than speaking what is right (דבר צדק). The 'practicing of deceit' and 'articulation of lies' thus occur as parallel descriptions of being dishonest in adjacent verse lines in Psalms 52:4-5 and 101:7. The two psalms seem to address the same social evils experienced in the late post-exilic Judean society, namely, the problem of arrogant, ${ }^{22}$ rich people ${ }^{23}$ who exploit powerless and poor people by lying to them and deceiving them, Jews who have abandoned their trust in Yahweh because they think that they do not need him, and who display their arrogance by bragging about their ill-gotten riches. In both psalms, the psalmist fights against this by putting his trust in the covenant love ('faithful love', intervene by removing the wicked people from society. ${ }^{24}$

\section{Similarities between Psalm 101 and some of the other wisdom psalms}

Psalm 1 defines the righteous person as one who does not associate with wicked people (רשים), sinners, or mockers, but who busies himself 'day and night' with the Torah of Yahweh (Psalm 1:1-2). This involvement with the Torah of Yahweh nourishes the righteous to be vibrant, fruitful, and successful (Psalm 1:3). Association with the Torah in turn implies that Yahweh associates himself with the righteous (he 'knows' their way, Psalm 1:6). The metaphor of life as a journey on a road (cf. the use of הרך in Psalm 1 and in Psalm 101:2a, 2c and 6c) and the repeated use of the negative particle לא to express rejection of association - both of the righteous with the wicked and the wicked with Yahweh and with the righteous ${ }^{25}$ - are replicated in Psalm 101.26 Psalm 101:7, which says that people who practises deceit will not 'dwell' (ישב) in the house of the psalmist, reminds the observant reader about Psalm 1:1, which describes the righteous as not 'sitting' (ישב) in the 'seat' or 'dwelling-place' (מושבב) of mockers. The judgement of the wicked, using the image of chaff in Psalm 1:4, comes to mind when one reads of the destruction of the wicked in Psalm 101:8, especially in view of the probable connections with Proverbs 2:22 ${ }^{27}$ and 20:26. ${ }^{28}$

22.For arrogance in Psalm 101, see verse 5 . Psalm 52 uses the rare form of 'boasting'

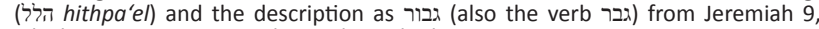
which prove a connection beyond any doubt.

23.In Psalm 52:9, the trust of the antagonist in 'his riches' is mentioned explicitly. The antagonists are not described as rich people in Psalm 101, but as arrogant people who slander fellow Israelites (101:5) and practice deceit and utter lies (101:7). The protagonists are called 'righteous people' (ציקים) and 'faithful people' (חיקיד) in Psalm 52:8 and 11, but are described as 'the faithful of the land' in Psalm 101:6 and those who 'walk in a blameless way' in Psalm 101:6.

24.Yahweh threatened to remove (inter alia with נo nif) disrespectful and obstinate Israelites from the land in Deut 28:63. Proverbs 2:22 applies this removal to the 'wicked' and 'treacherous' Israelites (using כרת al). Psalm 52:7 applies it to the 'arrogant evildoer' (using נס $q$ (al); while Psalm 101:8 applies it to the 'wicked' of the land, using כרת hif.

25. לא is used three times in Psalm 1:1 for the lack of association of the righteous with the wicked, and once (via elision) for the lack of association of the wicked with the righteous in Psalm 1:4. The use of ל in Psalm 1:4 refers in the first place to their lack of being able to defend themselves in judgement.

26. לא is used six times in Psalm 101 to express dissociation.

27.Cf. the use of כרת in Proverbs 2:22 and Psalm 101:8.

28.'A wise king winnows the wicked and turns the threshing wheel over them'. 
Since Psalms 1 and 2 were interlocked by the editors (through the inclusio created by the road metaphor and the blessing formula in Psalm 1:1 and Psalm 2:12), the close relationship of the king with Yahweh in Psalm 2, also comes to mind when one reads Psalm 101. The 'city of Yahweh' which the 'king' intends to rid of evildoers (Psalm 101:8), centres around Zion, the holy mountain of Yahweh (Psalm 2:6). ${ }^{29}$ His authority to rule over the 'ends of the earth' (אפסי-ארץ) and shatter the inhabitants like a clay vessel (Psalm 2:9), comes to mind when one reads of his intention to 'destroy all the wicked of the land (כל־רשעי־ארץ)' in the mornings (Psalm 101:8). As the kings of the world are advised to do (שכל hif, Psalm 2:10), the 'king' is focused on regarding his way of life in a wise way (שכל hif, Psalm 101:2).

Psalm 1-2, as the combined introduction to the Psalter, was composed and edited by exponents of wisdom teaching to reflect two possible responses to the invitation of Wisdom in Proverbs $1 .{ }^{30}$ Psalm 1 was composed to represent the correct, positive, and accepting response to the warnings and invitations in Proverbs 1:10 and 15 (not going with sinners on their way), 22 (avoiding mockers), and 4:14 (not going on the road of the wicked and evil people). Psalm 2, on the other hand, in its present form, reflects on the futility of a rejection of this invitation by the rulers of the world and reports on the amused response of Yahweh in the role of a wisdom teacher (cf. Psalm 2:4 with Proverbs 1:26). The rulers of the world are at the end of the psalm again called upon to have insight, reflecting a similarity with Proverbs 1 (cf. Psalm 2:10 with Proverbs 1:3). Psalm 101 closely resembles the combined effect of Psalm 1-2 as a unit. It serves as a declaration of dissociation from worthless and devious things, falsehood, evil and slandering, arrogance, deceit and lies - in short, from the wicked of the land, all evildoers and their actions. It constitutes simultaneously a confession of the intent of the royal speaker to walk in integrity of heart and associate with the faithful and blameless people of the land, but exterminate the wicked and the evildoers. There is a similarity between the intent to 'destroy' the wicked in Psalm 101:5 and 8 and the promise to the anointed king in Psalm 2:9 that he will 'break' and 'smash' the nations and the ends of the earth (and thus the foolish kings of the earth, cf. 2:2).

One last example of a psalm similarly influenced by post-exilic wisdom is Psalm 26.31 The poet of Psalm 26 pleads for vindication because he has 'walked' in 'integrity' (אני בתמי הלכתי, Psalm 26:1) and will keep on doing so (בתמי אלך, Psalm 26:11). There is an obvious parallel to Psalm 101:2. He also says that he keeps Yahweh's 'faithful love' (חסד) before his eyes (לנגד עיני) and 'walks' in Yahweh's 'faithfulness' (אמת) (Psalm 26:3), similar to the 'faithful love' and 'justice' of Yahweh that direct the conduct of the poet of Psalm 101. He then further dissociates himself from a whole group of people, saying that he does not 'sit' with 'men of falsehood' (מתי־שוא) or 'consort' with 'hypocrites' (עם־נעלמים לא אבוא, Psalm 26:4); that he 'hates'

29.Hossfeld and Zenger (2011:16) also interpret 'the city of Yahweh" as an adoption of the Zion tradition, akin to what we find in Psalms 2:6, 20:3, 110:2, and 132:13.

30.Cf. the detailed discussion in Gosse (2008:51-57).

31.Examples of similarities with wisdom psalms could be multiplied. Kselman (1985:54) refers to similarities between the use of in Psalm 101:2 and Psalm 25:21 as well as 37:37; and the 'eye' of Yahweh being on those who fear him in 25:21 as well as 37:37; and the 'eye' of Yahweh being on those who fear him in
Psalm 33:18 (cf. also 34:16) and that of the king in Psalm 101:6 (Kselman considers these to be the words of Yahweh).
(שנאתי) the assembly of 'evildoers' (מרעים) and will not 'sit' with the 'wicked' (עם־רשעים לא אשב, Psalm 26:5). In contrast to this, he 'loves' the house of Yahweh (Psalm 26:8). The similarities with Psalm 101 are obvious. Although Psalm 1 was written as a macarism, Psalm 26 in the form of a personal exculpation, and Psalm 101 in the form of a royal proclamation, the purposes of these texts are all very similar, namely, to encourage dissociation from unethical conduct, on the one hand, and strengthen association with moral prescripts, on the other.

\section{The purpose and meaning of Psalm 101 in its current location in Book IV of the Psalter}

Psalm 101 is the first Davidic psalm in Book IV of the Psalter. It is, in fact, the first psalm which has the words לדוד in its heading after Psalm 86, while only one other psalm in Book IV, namely, Psalm 103, also has this ascription. As such, it is regarded by some as a kind of Fremdkörper in a 'Mosaic' book of the Psalter. Yet, it is finely integrated into this book in which the kingship of Yahweh plays such an important role. The kingship of Yahweh is emphasised in Psalms 90-106 precisely because, after the harsh criticism of Psalm 89, it was necessary to state clearly that there is no 'unrighteousness' in Yahweh (cf. Psalm 92:15). He is the supreme judge of the world, who cannot act in an immoral way. It is consequently stressed through repetition that Yahweh is coming to judge the world with 'righteousness' (צדק) and 'equity' (אמונה) (cf. Psalm 94:2; 96:13; 98:9).

And yet, among Yahweh's own people, there are problems. Arrogant evildoers boast that Yahweh does not take notice of their wrongdoing (Psalm 94:3-4). ${ }^{32}$ Poor and powerless people are oppressed (Psalm 94:6), ${ }^{33}$ and the righteous and the upright in heart suffer as a consequence (Psalm 94:15). In response to this state of affairs, Psalm 101 is presented as the declaration of a king in Jerusalem, in which the speaker celebrates the realisation of his divine duty to promote the values esteemed by Yahweh by caring for his followers and undertaking to rid society of its evils. As a 'royal psalm', it was designed to promote certain ethical values by motivating members of the pious in-group to dissociate themselves from certain groups and certain types of conduct and associate themselves with like-minded people, and thus is very similar to the function of Psalms 1 and 26.

As the only 'royal psalm' in Book IV of the Psalter, Psalm 101 was designed to show how the kingdom of Yahweh would, in the end, manifest itself, namely through the exercise of moral choices by the 'faithful in the land'. The role of Yahweh as king in the 'Yahweh is king' Psalms, Psalms 93-100, is exercised by the royal speaker in Psalm 101 as a representative of all the faithful. As such the 'king' acts as 'judge of the earth' to punish the 'proud' (גאים, Psalm 94:2, cf. Psalm 101:5), the 'wicked' (כרים, Psalm 94:3, cf. Psalm 101:8), and the 'evildoers' (כל־פעלי און, Psalm 94:4, cf. the same expression in Psalm 101:8). They oppress the widow, sojourner, and fatherless (Psalm 94:6), while denying that Yahweh has any power to punish them (Psalm 94:7). In reply to the rhetorical question in Psalm 94:16 about who will

32. The same attitude is criticised in Psalms $52: 3,53: 2$, and $54: 5$.

33.The same actions are criticised in Psalms 52:4-6 and 53:5. 
oppose the wicked and the evildoers, Psalm 101 offers an emphatic answer. His earthly representative will do it! In this way, he himself will wipe them out through his anointed (cf. the repeated use of יצמית in Psalm 94:23 and the similar, repeated use of אצמית in Psalm 101:5 and 8). In the view of Martin Leuenberger (2004:244), Psalm 94 itself should be interpreted as a wellplanned and contextually well-integrated insertion (together with Psalm 97:10-12) into an already existing composition 90-92 and 93-100. This insertion probably coincided with the addition of 101-106, according to him. As the first Davidic psalm in Book IV, Psalm 101 represents a 'new beginning' after the 'Yahweh is king Psalms' 93-100 (Hossfeld \& Zenger 2011:16), looking forward to the establishment of Yahweh's kingdom on earth. ${ }^{34}$

Psalm 101 thus fulfils a very necessary function in Book IV. It provides hope to those who 'walk in a blameless way', to the 'faithful in the land'. It motivates them to trust in the justice of Yahweh, to hold fast to his kingship. It inspires them to work to establish his rule on earth by imitating the royal speaker of the psalm, oppose all forms of corruption and deceit and evil, to live their lives in compliance with the precepts of Yahweh, and associate with those who also remain faithful to him. Through meditating on this psalm, they in effect formulate a supplication to Yahweh to let this ideal state of affairs become a reality. ${ }^{35}$

\section{Conclusion}

Psalm 101 has a very precise, ${ }^{36}$ 'intertwined parallelistic' structure with strong influence from Proverbs and similarity to Torah-wisdom compositions. All three of these characteristics point towards its origin as a complete unit in post-exilic times under the influence of Torah-wisdom circles. ${ }^{37}$ It was probably composed by them in response to a need they perceived in society. It was time for the judge of the whole world to act (cf. $102: 13 ; 119: 126)$. The faithful Yahwists had to be encouraged to believe that he was indeed 'coming', so that they could help to establish his rule by embracing his ethical rules of conduct. ${ }^{38}$

34.According to Bremer (2014:17), the only reference to the "poor' which uses the 'classical' terminology, is to be found in the heading of Psalm 102. As he notes, Psalm 94 does, however, mention the 'personae miserae'. This reference in Psalm 94, together with the concern about social illnesses and the solution thereof in Psalm 101, probably serve to represent them in Book IV of the Psalter.

35.In the words of Saur (2010:695), referring to the theological function of the royal psalms as a group, 'Es hat zumindest den Anschein, als werde hier auf de vorexilischen Grundlage ein Königsbild entworfen, das in die Zukunft weist und dahe seinen Platz in einer Gebetssammlung findet, die ja nicht antiquarisch konzipiert ist, sondern die gegenwärtige Gebets- und Frömmigkeitspraxis prägen will'.

36.In the words of Kenik (1976:391-403, 394), '[t]he balanced structure and consistent grammatical pattern suggest a poetic composition designed with precision and care'.

37. Hossfeld and Zenger (2011:16) accept, on similar grounds, as well as the 'narrow scope' of the petitioner's public activities and the adoption of the Zion tradition in the psalm, that it originated as a royal psalm 'within the postexilic Persian period with its restorative-Davidic tendencies'.

38.As Saur (2010:698), formulates it: 'Mit dem Psalter, und das heisst: auf der Ebene der Frömmigkeit, wird zwischen Theokratie und (Proto-) Messianismus vermittel und der Versuch unternommen, auf dieser Grundlage eine Brücke zwischen den verschiedenen Trägergruppen zu schlagen: Die Herrschaft Jahwes is die souverän und umfassende Herrschaft, auf die zu hoffen ist; diese Herrschaft realisiert sich aber in der erhofften Gestalt eines von Jahwe eingesetzten Heilskönigs, der die Personalität der göttlichen Herrshcaft für alle sichtbar machen wird'.

\section{Acknowledgements Competing interests}

The author declares that he has no financial or personal relationships which may have inappropriately influenced him in writing this article.

\section{References}

Barré, M.L., 2005, 'The shifting focus of Psalm 101', in P.W. Flint \& P.D. Miller (eds.) The book of psalms: Composition and reception, pp. 206-223, Brill, Leiden. (Supplements to Vetus Testamentum 49).

Beyerlin, W., 1980, Der 52. Psalm, Studien zu seiner Einordnung, Kohlhammer, Stutttgart. (Beitrage zur Wissenschaft vom Alten und Neuen Testament).

Booij, T., 1988, 'Psalm C1 2 - “When wilt thou come to me?”, Vetus Testamentum 38 458-462.

Botha, P.J., 2004, 'Psalm 101: Inaugural address or social code of conduct?', HTS Teologiese Studies/Theological Studies 60, 725-741. http://dx.doi.org/10.4102/ hts.v60i3.624

Bremer, J., 2014, 'Strukturbeobachtungen zur armentheologie des Psalters', in M. Sauer, (Hg.), Die Kleine Biblia: Beiträge zur Theologie der Psalmen und des Psalters, pp. 1-36, Neukirchener Theologie, Neukirchen-Vluyn (Biblisch-Theologische pp. 1-36, Neut
Studien 245).

Dietrich, W.L., Köhler, Arnet, S. \& Dietrich, M, 2013, Konzise und aktualisierte Ausgabe des Hebräischen und aramäischen Lexikons zum Alten Testament (KAHAL), Brill, Leiden.

Gesenius, W., 1910, Gesenius's Hebrew Grammar, E. Kautzsch (ed.), transl. A.E. Cowley, Clarendon, Oxford.

Gosse, B., 2008, L'influence du livre des Proverbes sur les rédactions bibliques à l'époque perse, Gabalda, Paris.

Gunkel, H., [1929] 1986, Die Psalmen: Übersetzt und erklärt, 6. Auflage, Vandenhoeck \& Ruprecht, Göttingen.

Gunkel, H., [1933] 1985, Einleitung in die Psalmen. Die Gattungen der religiösen Lyrik Israels, zu Ende geführt von J Begrich, Ergänzungsband zur II. Abteilung. 4. Auflage, Vandenhoeck \& Ruprecht, Göttingen.

Hossfeld, F.-L. \& Zenger, E., 2011, Psalms 3: A commentary on Psalms 101-150, K. Baltzer (ed.), transl. L.M. Maloney, Fortress, Minneapolis, MN. (Hermeneia).

Kenik, H.A., 1976, 'Code of conduct for a king: Psalm 101', Journal of Biblical Literature 95, 391-403. http://dx.doi.org/10.2307/3265272

Kraus, H.-J., 1966, Psalmen, 1. Teilband. 3., unveränderte Auflage, Neukirchener: Neukirchen-Vluyn. (Biblischer Kommentar Altes Testament).

Kselman, J.S., 1985, 'Psalm 101: Royal confession and divine oracle', Journal for the Study of the Old Testament 33, 45-62. http://dx.doi.org/10.1177/03090 8928501003303

Leuenberger, M., 2004, Konzeptionen des Königtum Gottes im Psalter: Untersuchungen zu Komposition und Redaktion der theokratischen Bücher IV-V im Psalter, Theologischer Verlag Zürich, Zürich. (Abhandlungen zur Theologie des Alten und Neuen Testaments 83).

Loader, J.A., 2014, Proverbs 1-9, Peeters, Leuven. (Historical Commentary on the Old Testament).

Loretz, O., 1988, Die Königspsalmen: Die altorientalisch-kanaanäische Königstradition in jüdischer Sicht. Teil 1: Ps 20, 21, 72, 101 und 144, mit einem Beitrag von I. Kottsieper zu Papyrus Amherst, Ugarit-Verlag, Münster. (Ugaritisch-Biblische Literatur, 6).

Mathys, H.-P., 1994, Dichter und Beter: Theologen aus spätalttestamentlicher Zeit, Universitätsverlag, Freiburg. (Orbis Biblicus et Orientalis 132).

Mowinckel, S., 1962, The Psalms in Israel's worship, Vol. I., transl. D.R. Ap-Thomas, Blackwell, Oxford.

Saur, M., 2010, 'Die Theologische Funktion der Königspsalmen innerhalb der Komposition des Psalters', in E. Zenger (ed.), The composition of the book of Psalms, pp. 689-699, Peeters, Leuven. (Bibliotheca Ephemeridum Theologicarum Lovaniensium).

Seybold, K., 1996, Die Psalmen, Mohr, Tübingen. (Handbuch zum Alten Testament 1/15)

Van der Lugt, P., 2014, Cantos and Strophes in Biblical Hebrew Poetry III: Psalms 90-150 and Psalm 1, Brill, Leiden. (Oudtestamentische Studiën, 63).

Weiser, A., 1975, The Psalms: A commentary, transl. H. Hartwell, SCM, London. (Old Testament Library). 